\title{
Molecular Detection, Histopathology, and Scanning Electron Microscopy of Myxobolus koi Infecting Cyprinus carpio Koi
}

\author{
Rachmat Noer Soelistyoadi ${ }^{1 *}$, Uun Yanuhar ${ }^{2}$, Maftuch² \\ ${ }^{1}$ Master Program of Aquaculture, Faculty of Fisheries and Marine Sciences, University of Brawijaya, Malang, Indonesia \\ ${ }^{2}$ Faculty of Fisheries and Marine Sciences, University of Brawijaya, Malang, Indonesia
}

\begin{abstract}
Myxobolus koi is a type of parasite that infects many freshwater fish through myxospores, resulting in a disease called myxobolosis. This research aimed is to investigate the clinical symptoms that occur in the gills of infected Koi carp ( $C$. carpio). The utilized methods in this study are molecular detection, histopathology, and Scanning Electron Microscopy (SEM). Koi carp samples that are suspected to be infected with Myxobolus koi show several clinical signs, such as swollen and pale-colored gills and gill covers (opercula) that do not close completely, as well as white spots that appear on the edge of the lamella. The results of this study showed that through histological observations, there were changes characterized by hyperplasia of the primary lamella cartilage that envelops parasitic cysts and the encapsulation process that surrounds the cysts by gill cartilage in infected fish; SEM showed oval and elongated spores of a size of $\pm 12 \mu \mathrm{m}$ (800x). The DNA template from gill tissues in clinically infected and uninfected fish was examined by PCR testing with primers ERB 1 (Forward) and ERB 10 (Reverse); the results of electrophoresis in infected fish were detected at $2000 \mathrm{bp}$.
\end{abstract}

Keywords: Cyprinus carpio, Histopathology, Molecular Detection, Myxobolus koi, Parasite, SEM.

\section{INTRODUCTION}

Globally, the aquaculture industry in the ornamental fish sector has grown rapidly in recent decades [1,2]. The value of global trade in ornamental fish estimated at more than 15 million dollars, with an annual growth of $8 \%$. One of these ornamental fish is koi fish, which is an ornamental strain of carp (Cyprinus carpio) $[3,4]$.

With the increasing demand for trade in ornamental fish, there is an increased risk of cross-sectional spread of several pathogens. Trade in the ornamental fish industry has indirectly moved millions of fish every year around the world, in some cases resulting in myxozoan parasites moving to new areas that cause pathological changes and death among fish [5]. Myxozoan parasites are a type of cnidarian endoparasites that are widely distributed throughout the world and cause economic losses in fisheries and aquaculture. Deaths from Myxobolus koi have also been reported in koi that transferred from Asia to the United Kingdom and the United States [6]. Myxobolus koi is a type of myxozoan parasite that infects many freshwater fish, resulting in a disease called myxobolosis. Myxobolosis that infect the gills of carp in the juvenile stage results in large losses $[7,8]$. At present, there are 29 Myxobolus species

\footnotetext{
*Correspondence Address:

Rachmat Noer Soelistyoadi

E-mail : rachmatns96@gmail.com

Address : Faculty of Fisheries and Marine Sciences, University of Brawijaya, Veteran Malang, 65145.
}

known as parasites of C. carpio, of which 17 infect the gills [9]. Myxozoans are among the most abundant parasites in nature $[10,11]$. Their life cycles involve two hosts: an invertebrate, usually an annelid, and a vertebrate, usually a fish $[12,13]$. They affect fish species in their natural habitats but also constitute a menace for fish aquaculture $[14,17]$.

Gill myxobolosis due to Myxobolus koi (Myxozoa; Myxosporea) (Kudo, 1920) of common carp (Cyprinus carpio) juveniles have been known to occur occasionally in Japanese carp culture and cause serious damage to fish farmers in 1978 [7]. Attacks of Myxobolus found in Indonesia in 1974 and 1978, which caused the death of up to $100 \%$ of koi fish, especially in the juvenile phase [18].

In 2013, Myxobolus koi was included in the list of Class I Quarantine of Fish Pests and Diseases in the parasite type by Ministry of Fishery and Maritime Affairs Decision Number 26/Kepmen-Kp/2013 on the Establishment of Quarantine of Fish Pest and Disease Types, Groups, Carrier Media, and Their Distribution, which means that if this kind of parasite is found in carrier media, destruction must be carried out. [19]. Fish diseases are usually difficult to control and cure; when the disease infection has taken place, it is often late for its management and the prevention of greater losses. It becomes very important to find out the health level of fish [20].

Clinical parameters and zootechnical indices have been regarded as insufficient to monitor fish health during early infection. Therefore, in addition to traditional markers (biochemistry, 
histology, morphology, and physiology), it is important to look for alternative parameters such as molecular biomarkers [21,22,23]. The genome strategy is revolutionizing scientific research in understanding fish physiology and gene evolution because it is relatively easy to isolate novel genes and homologs using public databases $[24,25]$. The aim of this research is to investigate the clinical symptoms that occur in the gills of Koi carp (C. carpio) infected by Myxobolus sp. The utilized methods are traditional methods (histopathology, SEM) as well as the molecular detection method, which are seen as the most representative and effective methods for checking the health level of fish.

\section{MATERIALS AND METHODS}

\section{Sampling}

Juvenile koi (Cyprinus carpio) of approximately $5-7 \mathrm{~cm}$ in length and 8-10 grams in weight were obtained from ponds in Kemloko and Kedungwaru Villages of Nglegok Sub-District in Blitar, Province of East Java. Eight samples were collected from December 2018 to January 2019. The live fish were transported to the Bioscience Laboratory of Brawijaya University and the Molecular Biology Laboratory of the Class I Fish Quarantine and Inspection Agency of Surabaya.

For Scanning Electron Microscopy and molecular identification, taking gills of the test fish and preserved in 95\% ethanol solution steps was conducted according to the protocol $[26,27]$. Fish gills containing plasmids were fixed with Davidson solution, gradient-dehydrated, embedded in paraffin wax and sectioned at 3-5 $\mu \mathrm{m}$, and given color with hematoxylin and eosin [28]. Ethanol-preserved plasmids were used for genomic DNA extraction according to the procedure recommended by the manufacturer [29].

\section{Histopathology Study}

Making of Histological Block Tissue

1. Specimens were fixed using Davidson solution for a maximum of 24 hours and then transferred to a $10 \%$ formalin buffer solution.

2. Samples were cut into small pieces measuring $\pm 1 \mathrm{~cm}$. The samples were inserted into a cassette or specimen container and labeled according to the sample number.

3. These were inserted into a tissue processor container and the device was programmed accordingly.
4. The dehydration process used multilevel alcohol solutions ranging from $70 \%, 80 \%(2 x$ replications), to $85 \%$, each for 2 hours. Subsequent processing used pure alcohol, conducted 3 times each for two hours.

5. The clearing process used xylene, with 3 replications each for 30 minutes.

6. The embedding process utilized liquid paraffin at a temperature of $58^{\circ} \mathrm{C}$, with 2 replications each for 2 hours.

7. Blocking was performed by removing the specimens from the cassette to be printed using a paraffin mold, then the block was put in the freezer for 5 minutes. The block was removed from the mold and trimmed by forming a $1.5 \mathrm{~cm}$ square.

8. By using a microtome, the tissue was cut to a thickness of 3-5 $\mu$ and immediately floated in a water bath filled with distilled water heated to $50^{\circ} \mathrm{C}$. Paraffin tape was removed using a glass, and the object was air-dried and labeled.

\section{Coloring of Histological Tissue}

1. The tissue pieces that have been attached to the glass are arranged in a staining jar and then inserted into an incubator at $37^{\circ} \mathrm{C}$ for 1 hour, and the glass is dried.

2. The deproteination process was carried out using a xylene solution with 2 repetitions each for 5 minutes.

3. Dehydration was performed using alcohol starting from pure alcohol to $95 \%$ alcohol, with 2 repetitions 10 times for each dye, or \pm 1 .

4. Rinsing was performed 10 times with distilled water.

5. Next, the coloring process used Hematoxylin dye for 2 minutes, before rinsing with running water for 5 minutes and followed by eosin staining for 10 minutes.

6. The dehydration process used alcohol starting from pure alcohol to $95 \%$ alcohol.

7. The clearing process used xylene, with 2 repetitions for 10 times or \pm 1 minute.

8. For mounting, slides containing pieces of tissue were removed from the staining jar one by one and then covered with a glass cover that had been given an Entellan solution.

9. Tissue preparations were then observed under a microscope with 40x magnification for analysis.

10. Existing tissue abnormalities were observed $[26,28]$. 


\section{Scanning Electron Microscopy}

For SEM analysis of the myxozoan parasites, $2.5 \%$ glutaraldehyde fixation solution was administered for two hours at $4{ }^{\circ} \mathrm{C}$, followed by dehydration with ethanol and air-drying. The sample was then coated with metallic platinum in an IB-2 ion counter and examined with a ZEISS Scanning Electron Microscope at an accelerating voltage of $15.00 \mathrm{KV}$ with $10.00 \mathrm{KX}$ magnification. The host fish was examined and fixed in $2.5 \%$ glutaraldehyde solution for two hours at $4{ }^{\circ} \mathrm{C}$, followed by dehydration with ethanol and rinsing with pure acetone and mixtures with amyl acetate in 3:1, 2:2, and 1:3 ratios, and finally with $100 \%$ amyl acetate. The tissues were then dried at critical point using $\mathrm{CO}_{2}$ in a HCP:2 Critical Point Dryer (Hitachi), coated with metallic gold at accelerating voltages of 15 and $20 \mathrm{KV}[26,27]$.

\section{DNA Extraction}

DNA was extracted using the Silica Extraction Kit (Gene) from tissues preserved in pure ethanol solution. Each gill and intestinal tissue sample identified as Myxobolus-infected or healthy was inserted into $1.5 \mathrm{~mL}$ microtubes, to which $900 \mu \mathrm{l}$ GT Buffer is added before being mashed with a grinding pestle and centrifuged at a speed of $12000 \mathrm{rpm}$ for 3 minutes. The $600 \mu$ layers were put into new $1.5 \mathrm{~mL}$ microtubes, given $40 \mu \mathrm{L}$ of silica, vortexed until homogeneous, and centrifuged at a speed of $12000 \mathrm{rpm}$ for 15 seconds (no more than 20 seconds). After centrifuging, the solution was discarded and the silica pellets were washed with $500 \mu \mathrm{L}$ GT Buffer, vortexed until a suspension was formed, and centrifuged at a speed of $12000 \mathrm{rpm}$ for 15 seconds (no more than 20 seconds). The solution was discarded again and $1 \mathrm{ml} 70 \%$ ethanol was added to rinse the silica pellets, vortexed until a suspension was formed and centrifuged at 12000 rpm for 15 seconds (no more than 20 seconds). The ethanol was removed and any remaining ethanol was taken by a micropipette. The silica pellet was re-suspended in $1 \mathrm{ml}$ of $\mathrm{ddH} 2 \mathrm{O}$, vortexed until the silica pellet forms a suspension, incubated at $55^{\circ} \mathrm{C}$ for 10 minutes, homogenized with a vortex machine, and centrifuged at a speed of $12000 \mathrm{rpm}$ for 2 minutes. $500 \mu$ l of the top solution was put into new microtubes and the total amplification process was performed with a PCR reaction mixture volume of $25 \mu \mathrm{L}$, which consists of Master Mix (KAPABiosytems, KK510) and $2 \mu \mathrm{L}$ Forward Primer (ERB1), $2 \mu \mathrm{L}$ Reverse Primer
(ERB10), $2 \mu \mathrm{L}$ Template DNA, and $19 \mu \mathrm{L}$ Nucleasefree water $[9,29]$. The primer composition can be seen in Table 1.

Table 1. List of Primers for PCR

\begin{tabular}{clll}
\hline No & Primer & Sequence (5'-3') & Size (bp) \\
\hline 1 & ERB1 (F) & ACCTGGTTGATCCTGCCAG & $2-20$ \\
2 & ERB10 (R) & CCTCCGCAGGTTCACCTACGG & 2079-2059 \\
\hline \multicolumn{2}{c}{ Source: Scientific journals [7] }
\end{tabular}

\section{Amplification}

Pre-denaturation was performed at the temperature setting of $94^{\circ} \mathrm{C}$ for 2 minutes, followed by denaturation at $94^{\circ} \mathrm{C}$ for 1 minute, annealing at $58^{\circ} \mathrm{C}$ for 1 minute, extension at $72^{\circ} \mathrm{C}$ for 1 minute 30 seconds for 35 cycles, and final elongation at $72^{\circ} \mathrm{C}$ for 5 minutes [29].

\section{Electrophoresis}

The results of DNA amplification were examined using agarose gel $1.5 \%$ soaked with $1 \mathrm{X}$ Tris Acetate-EDTA (TAE). The holes in the gel were filled sequentially with $100 \mathrm{bp}$ DNA Ladder markers (Geneaid, Nexmark), $8 \mu \mathrm{L}$ of amplification, and control blanks [29]. The PCR products were analyzed on $1.5 \%$ agarose gel containing $0.5 \mathrm{mg} \cdot \mathrm{mL}^{-1}$ ethidium bromide in $1 \mathrm{X}$ Tris Acetate-EDTA (TAE) buffer and the size was estimated by comparison with $100 \mathrm{bp}$ of invitrogen DNA Ladder [30,31]. The electrophoresis process was carried out for 45 minutes with a voltage of 100 volts. The gel was placed in gel documentation, observed under UV light, and documented [29]. The tool for taking electrophoresis images is the BioDoc System Imaging tool.

\section{RESULTS AND DISCUSSION Fish Infection}

Koi carp samples that were suspected to be infected with Myxobolus koi can be seen in Figure 1. The gills had swollen and become pale in color, and the gill cover (operculum) did not close completely (Fig. 1a). White spots also appeared on the edge of the lamella. Figure $1 b$ shows the pale red gills along with spots on the gills. The observed primary and secondary lamellae are shown to have merged in the figure. One of the symptoms of Myxobolus koi infections in Koi carp is the appearance of parasite cysts in the gills [32]. The fish were in fair physical condition, though the gills were characterized grossly by widespread, multifocal coalescence, with 2-3 mm nodular white foci $[9,33,34]$. 


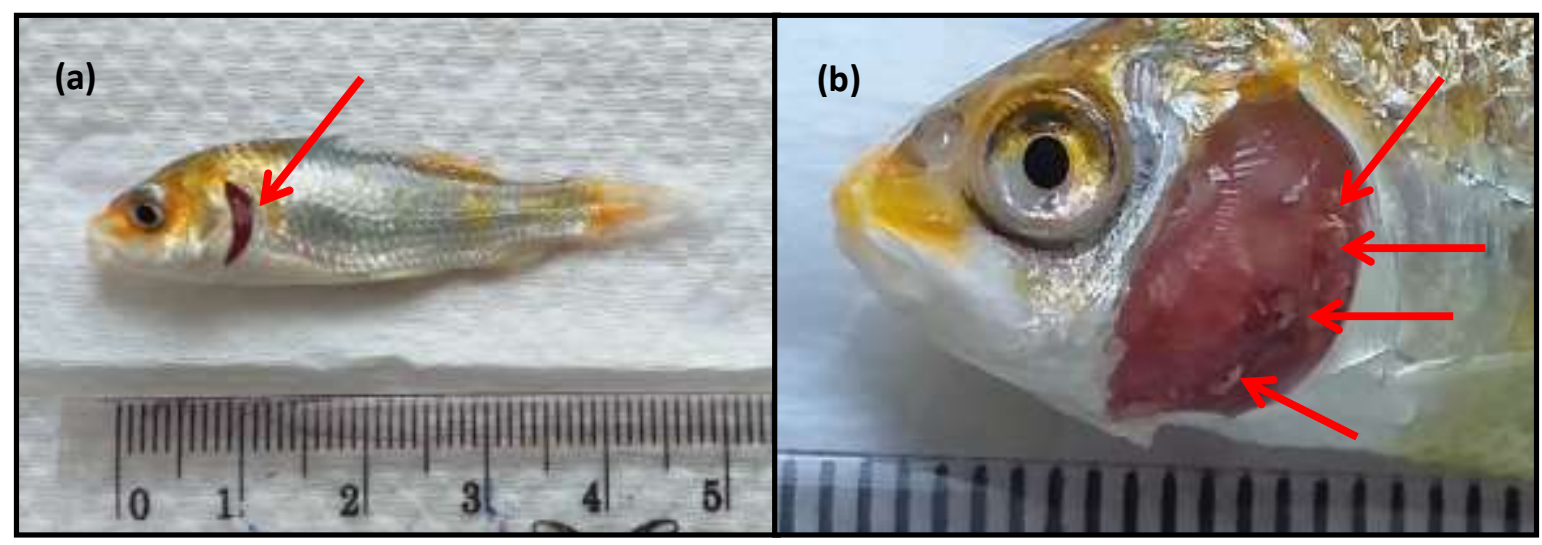

Figure 1. Koi gills infected by the Myxobolus koi parasite; (a) operculum did not close completely, (b) nodules in the gills

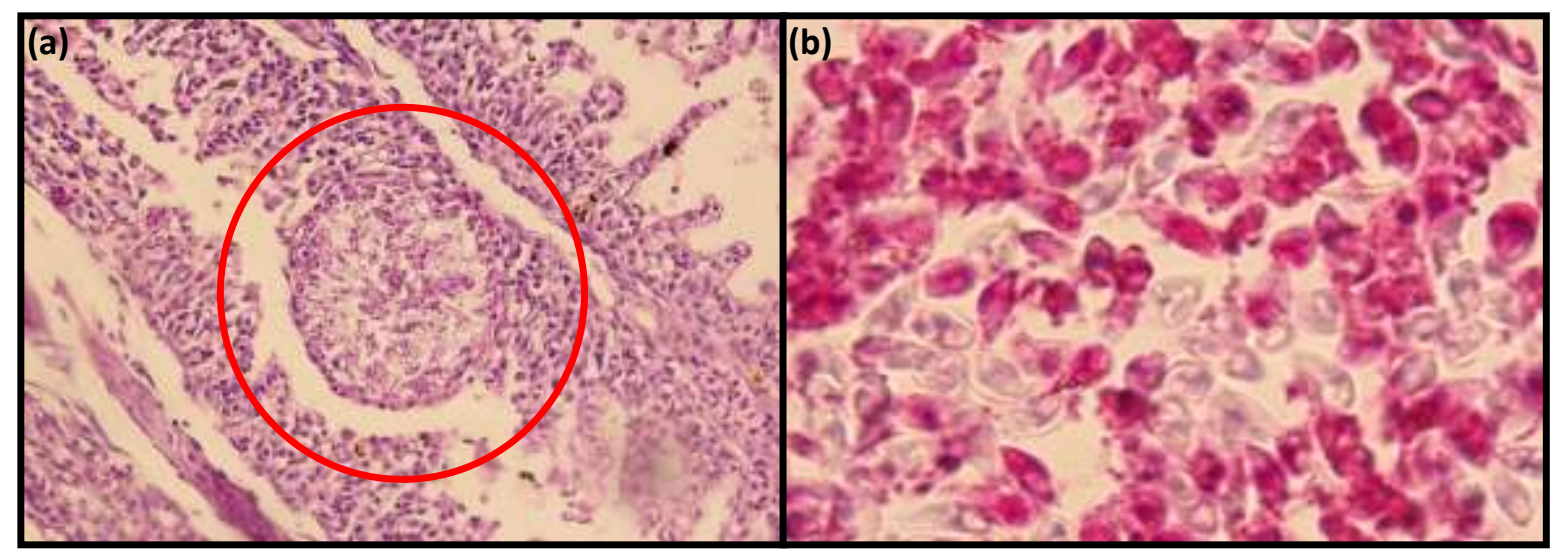

Figure 2. Histological sections of Cyprinus carpio gills showing location of Myxobolus koi tissue infection

(a) Gills showing plasmodia in gill lamellae (100x) (b) Myxobolus koi spores in gill lamellae (1000x)

\section{Gill Histopathology}

The gills function as a breathing apparatus, but also function to regulate the exchange of salt and water between the body and the environment and play a role in removing nitrogen-containing wastes $[34,35,36]$. Structural damage in the gills of fish very much influences the regulation of osmosis, disrupting breathing and osmoregulation processes of fish [37,38].

Plasmodia are commonly found in gill filaments and are generally located in the middle of the gill lamella [39]. Gill histopathological studies show the number of plasmids and parasites in gills with little cell hypertrophy and epithelium [39]. Histological analysis showed that plasmodia developed in the lumen of flat capillaries and in the encapsulation process with gill filaments (Fig. 2a). Myxobolus koi spores in the gill lamella can be seen in Figure $2 b$. However, the rest of the gill lamellae and cartilage structure remained intact. There was no inflammation and swelling or infiltration of inflamed cells in one of the examined histological slides [33]. In the infected fish, there were only changes characterized by hyperplasia of the primary lamella cartilage that envelops parasitic cysts and the encapsulation process that surrounds the cysts by gill cartilage [46].

\section{Scanning Electron Microscopy (SEM)}

Some features of the myxozoan spores are more specifically disclosed through SEM. Plasmid spores that cover the gills will inhibit the process of absorption of oxygen by the gill lamella. Myxobolus koi specifically attacks the gills in the gill arches and filaments [32]. In Figure 3, the spores appear to break out of the gills and cover the lamella section. The spores are oval and elongated, with a size of $\pm 12 \mu \mathrm{m}$ (800x).

\section{Molecular Detection}

Initially, identification with spore morphology was used for the basis of identification of myxozoan species. In the early 1990s, phenotypic features such as hosts, organs, and tissue specificity were used as important characteristics for specific identification $[40,41,42]$. Then, 
several studies confirmed the importance of molecular features, and in some cases, they have been found to correlate with the results of molecular data based on the 18S rDNA sequence comparison $[34,43]$.

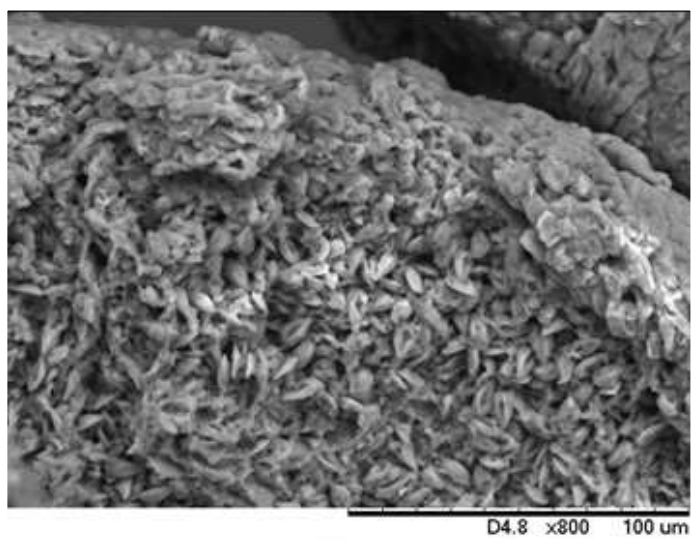

Figure 3. Scanning electron microscopy of Myxobolus koi spores, gill lamellae of Cyprinus carpio showing coverage with spores (Scale bar $=$ $100 \mu \mathrm{m} ; 800 \mathrm{x}$ )

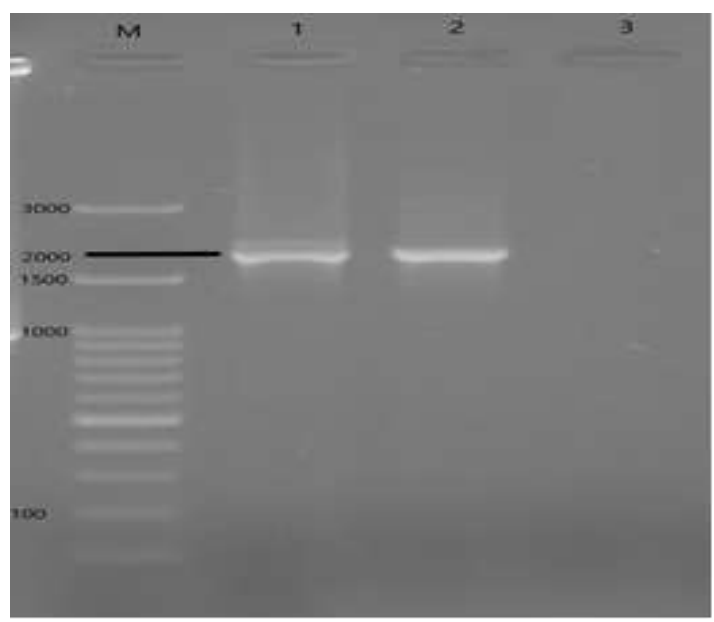

Figure 4. Agarose gel (1.5\%) showing $18 \mathrm{~S} r$ DNA gene amplification of Myxobolus koi DNA (2000bp) from Cyprinus carpio.

Description:

M: Marker/DNA ladder;

1: Myxobolus koi DNA (K+),

2: Positive Myxobolus koi,

3: Negative Myxobolus koi

PCR testing with specific primers in the DNA template amplification process will only display the appropriate band. DNA from gill tissue in clinically infected and uninfected fish was examined by PCR with specific primers (ERB1 Forward and ERB10 Reverse) to find the presence of the Myxobolus koi parasite. [44,45]. The results of electrophoresis can be detected at 2000 bp. DNA-based examination with molecular techniques has several advantages over microscopic observation because it is very specific and sensitive, and thus it can detect infections at an early stage and very mild infections [25]. In Figure 4, the appearance of the band in lane 2 shows the copy of Myxobolus koi genome in the target organ sample, whereas in lane 3, the band does not appear, presumably due to the absence of a copy of the Myxobolus koi genome or the very small volume of the genome that is undetectable with the nested PCR method.

\section{CONCLUSION}

For the present study, the myxosporean parasite Myxobolus koi was found to have infected the gill lamellae of Cyprinus carpio cultivated in Blitar, East Java. The present species was described based on morphology, SEM, histopathology, and molecular detection with specific primers. The Myxobolus koi parasite can be detected by positive samples marked by checking using Nested PCR, with positive control found at 2000 bp. Molecular detection with specific primers is the most effective method because it can detect early stages of infection, mild infection without clinical symptoms, and specific species that infect the host.

\section{ACKNOWLEDGMENTS}

Gratitude is due to the Ministry of Fishery and Maritime Affairs who has funded the research and its publication, as well as to the laboratory staff of the Fish Quarantine and Inspection Agency of Surabaya I for facilities and assistance.

\section{REFERENCES}

[1] Mathews, P.D., O. Mertins, J.O.L. Pereira, A.A.M. Maia, E.A. Adriano. 2018. Morphology and 18S RDNA sequencing of Henneguya peruviensis n. Sp. (Cnidaria: Myxosporea), a Parasite of the Amazonian Ornamental Fish Hyphessobrycon loretoensis from Peru: A Myxosporean Dispersal Approach. Acta Tropica. 187.207-13. https://doi.org/10.1016/j.actatropica.2018.0 8.012.

[2] Camus, A.C., J.A. Dill, T. G. Rosser, L.M. Pote, M.J. Griffin. 2017. Myxobolus axelrodi n. sp. (Myxosporea: Myxobolidae) a parasite infecting the brain and retinas of the cardinal tetra Paracheirodon axelrodi (Teleostei: Characidae). Parasitol. Res. 116. 387-397. DOI 10.1007/s00436-016-5301-1.

[3] Safari, O., M. Sarkheil. 2018. Dietary administration of Eryngii mushroom 
(Pleurotus Eryngii) powder on haematoimmunological responses, bactericidal activity of skin mucus dan growth performance of koi carp fingerlings (Cyprinus Carpio Koi). Fish Shellfish Immun. 80. 50513. https://doi.org/10.1016/j.fsi.2018.06.046

[4] Dyková, I., I. Fiala, P. Nie. 2003. New data on Myxobolus longisporus (Myxozoa: Myxobolidae), a gill infecting parasite of carp, Cyprinus carpio haematopterus, from Chinese lakes. Folia Parasitologica. 50. 263268.

[5] Kiruba-Sankar, R., J.P. Raj, K. Saravanan, K.L. Kumar, J.R.J. Angel, A. Velmurugan, S.D. Roy. 2018. Invasive species in freshwater ecosystems - threats to ecosystem services Chapter 9. Biodiversity and Climate Change Adaptation in Tropical Islands. Elsevier Inc.

[6] Kajungiro, R.A., L. Xue, M. Aynealem. 2015. Molecular cloning and expression patterns of two Tumor Necrosis Factor Alpha genes in Crucian Carp (Carassius carassius). Mol. Biol. 49(1). 120-129.

[7] Yokohama, H., D. Inoue, A. Kumamaru, H, Wakabayashi. 1997. Myxobolus koi (Myxozoa: Myxosporea) forms large-and small- type 'cysts' in the gills of common carp. Fish Pathol. 32(4).211-217.

[8] Ahmed, I., I. Ahmad, S.A. Dar, M. Awas, H. Kaur, B.A. Ganai, B.A. Shah. 2019. Myxobolus himalayaensis sp. nov. (Cnidaria: Myxozoa) parasiting Schizothorax richardsonii (Cyprinidae: Schizothoracinae) from River Poonch in North West Himalaya, India. Aquacult. Rep. 14. 100192. https://doi.org/ 10.1016/j.aqrep.2019.100192.

[9] Camus., A.C., M.J. Griffin. 2010. Molecular characterization and histopathology of Myxobolus koi infecting the gills of a koi, Cyprinus carpio, with an amended morphological description of the agent. J. Parasitol. 96(1), 116-124.

[10] Dezfuli, B.S., G. Castaldelli, L. Gia. 2017. Histopathological and ultrastructural assessment of two mugilid species infected with Myxozoans and Helminthes. J. Fish Dis. 1-9. http://dx.DOI: 10.1111/jfd.12713

[11] Zhang, B., Z. Gua, Y. Liu. 2018. Morphological, histological and molecular characterization of three Myxobolus Species (Cnidaria: Myxosporea) from silver carp Hypophthalmichthys molitrix Valenciennes and bighead carp Hypophthalmichthys nobilis Richardson in China. Parasitol. Int. 67
509-516. https://doi.org/10.1016/j.parint. 2018.04.011.

[12] Gomez, D., J.O. Sunyer, I. Salinas. 2013. The mucosal immune system of fish: The evolution of tolerating commensals while fighting pathogens. Fish Shellfish Immun. 35(6). 1729-1739. http://dx.doi.org/10.1016 /j.fsi.2013.09.032

[13] Gómez., D, J. Bartholomew, J.O. Sunyer. 2014. Biology and mucosal immunity to myxozoans. Dev. Comp. Immunol. 43. 243256.

[14] Kabata, Z. 1985. Parasites and diseases of fish cultured in the tropics. Taylor and Francis Ltd.

[15] Kaur, H., R. Attri, J. Joshi. 2016. Molecular identification of a new myxozoan, Myxobolus dermiscalis $n$. sp. (Myxosporea) infecting scales of Labeo rohita Hamilton in Harike Wetland, Punjab (India). Int. J. Parasitol. Par. Wildlife. 5. 139-144.

[16] Adriano, E.A., S. Arana, M.M. Carriero, J. Naldoni, P.S. Ceccarelli, A.A.M. Maia. 2009. Light, electron microscopy and histopathology of Myxobolus salminus n. sp., a parasite of Salminus brasiliensis from the Brazilian Pantanal. Vet. Parasitol. 165. 25-29.

[17] Roberts, H.E., B. Palmeiro, E.S. Weber. 2009. Bacterial and parasitic diseases of pet fish. Vet. Clin. Exot. Anim. 12. 609-638.

[18] Mahasri, G. 2017. Development of spore protein of Myxobolus koi as an immunostimulant for prevent of myxobolusis on Gold Fish (Cyprinus carpio Linn) by oral immunisation. IOP Conf. Ser. Earth Environ. 55. Available at: https://iopscience.iop.org /article/10.1088/1755-1315/55/1/012009.

[19] Ministry of Marine Affairs and Fisheries, Republic of Indonesia. 2013. Decree No. 26/KEPMEN-KP/2013 about capture fisheries in the state area of fisheries management in the Republic of Indonesia. Available at: www.bkipm.kkp.go.id.

[20] Tonguthai, K. 1997. Control of freshwater fish parasites: a Southeast Asian perspective. Int. J. Parasitol. 21(10). 1185-I 191.

[21] Huss, R. 2015. Biomarkers Chapter 19: translational regenerative medicine. Elsevier Inc.

[22] Puntmann, V.O. 2009. How-to guide on biomarkers: biomarker definitions, validation and applications with examples from cardiovascular disease. Postgrad. Med. J. 85. 538-545. 
[23] Tom, M., M. Auslander. 2005. Transcript and protein environmental biomarkers in fish-a review. Chemosphere. 59. 155-162.

[24] Gornati, R., E. Papis, S. Rimoldi, V. Chini, G. Terova, M. Prati, M. Saroglia, G. Bernardini. 2005. Molecular markers for animal biotechnology: sea bass (Dicentrarchus labrax, L.) HMG-CoA reductase mRNA. Gene. 344. 299-305

[25] Jeon, C.H, J.W. Do, U.H. Nam, W.S. Kim. J.H. Kim. 2017. Development of PCR method for detecting Kudoa iwatai (Myxozoa: Multivalvulida) from rock bream Oplegnathus fasciatus. Parasitol. Res. 116. 789-796. DOI 10.1007/s00436-016-5354-1.

[26] Saha, M., P.K. Bandyopadhyay. 2017. Parasitological and histological analysis of a new species of the genus Thalohanellus and description of a myxozoan parasite (Myxosporea: Bivalvulida) from cultured ornamental goldfish, Carassius auratus L.I. Aquacult. Rep. 8. 8-15.

[27] Adriano, E.A., S, Arana, P.S. Ceccarelli, N.S. Cordeiro. 2002. Light and scanning electron microscopy of Myxobolus porofilus sp. n. (Myxosporea: Myxobolidae) infecting the visceral cavity of Prochilodus lineatus (Pisces: Characiformes: Prochilodontidae) cultivated in Brazil. Folia Parasitologica. 49. 259-262.

[28] Fish Quarantine Center, Fishery Product Quality and Safety Control Class I Surabaya I. 2017. Fish Pathology by Histological Technique. Work Procedure in Laboratory Testing. Fish Quarantine Center. Surabaya.

[29] Nurekawati, A.D, G. Mahasri, M. Yunus. 2016. Identifikasi Myxobolus sp. pada Famili Cyprinidae dengan metode molekuler di Provinsi Jawa Timur dan Jawa Tengah. Jurnal Biosains. 18(2). http://dx.doi.org/10.23/bsn. v18i2.3131.

[30] Gupta, A., H. Kaur. 2017. A new pathogen, Myxobolus holzerae (Myxosporea: Myxozoa) causing severe gill disease in an Indian major carp Labeo rohita in a cold water wetldan, Punjab (India). Microb. Pathog. 111. 244251.

[31] Gupta, A., H. Kaur. 2018. Myxobolus okamurae sp. nov. (Myxosporea: Myxozoa) causing severe gill myxoboliosis in the cyprinid Labeo bata in a cold water wetland, Punjab (India). Microb. Pathog. 115. 86-92.

[32] Maftuch, M., E. Sanoesi, I. Farichin, B.A. Saputra, L. Ramdhani, S. Hidayati, N. Fitriyah, A.A. Prihanto. 2018. Histopathology of gill, muscle, intestine, kidney, dan liver on
Myxobolus sp.-infected Koi carp (Cyprinus carpio). J. Parasit. Dis. 42(1). 137-143.

[33] Paperna, I. 1991. Diseases caused by parasites in the aquaculture of warm water fish. Ann. Rev. Fish Dis. 155-194.

[34] Guo, Q., M. Huang, Y. Liu, X. Zhang, Z. Gu. 2018. Morphological plasticity in Myxobolus bütschli, 1882: a taxonomic dilemma case and renaming of a parasite species of the common carp. Parasites \& Vectors. 11. 399. https://doi.org/10.1186/s13071-018-2943-0

[35] Koppang, E.O., A. Kvellestad, U. Fischer. 2015. Fish mucosal immunity: gill (Chapter 5). Mucosal Health in Aquaculture. Elsevier Inc.

[36] Evans, D.H., P.M. Piermarini, C.P. Choe, 2005. The multifunctional fish gill: dominant site of gas exchange, osmoregulation, acidbase regulation, and excretion of nitrogenous waste. Physiol. Rev. 85. 97-177.

[37] Sukarni., Maftuch., H, Nursyam. 2012. Kajian penggunaan Ciprofloxacin terhadap histologi insang dan hati Ikan Botia (Botia macracanthus, Bleeker) yang diinfeksi bakteri Aeromonas hydrophila. J. Exp. Life Sci. 2(1). 6-12.

[38] Hadi. A.A., S.F. Alwan. 2012. Histopathological changes in gills, liver and kidney of fresh water fish, Tilapia zillii, exposed to aluminum. Int. J. Pharm. Life Sci. 3(11). 20712081.

[39] Liu, X.H., S. Yuan, Y.L. Zhao, P. Fang, H. Chen, J.Y. Zhang. 2016. Morphological and molecular characterization of Myxobolus sheyangensis n. sp. (Myxosporea: Myxobolidae) with intralamellar sporulation in allogynogenetic gibel carp, Carassius auratus gibelio (Bloch) in China. Parasitol. Res. 115. 3567-3574. DOI 10.1007/s00436016-5122-2.

[40] Eszterbauer, E. 2004. Genetic relationship among gill-infecting Myxobolus species (Myxosporea) of cyprinids: molecular evidence of importance of tissue-specificity Dis. Aquat. Org. 58. 35-40.

[41] Andree, K.B., E. Mac Connell, R.P. Hendrick. 1998. Nested Polymerase Chain Reaction for the detection of genomic DNA of Myxobolus cerebralis in rainbow trout Oncorhynchus mykiss. Dis. Aquat. Org. 34. 145-154.

[42] Dar, S.A., H, Kaur, M.Z. Chishti. 2017. First record of Myxozoan parasites from fresh water fishes of Jammu and Kashmir and their pathogenecity. Microb.Pathog. 05. 138-144. 
[43] Buchmann, K., H.C. Slotved, D. Dana. 1993. Epidemiology of gill parasite infections in Cyprinus carpio in Indonesia and possible control methods. Aquaculture. 118. 9-21.

[44] Grabner, D.S., H. Yokoyama, S. Shirakashi, R. Kinam. 2012. Diagnostic PCR assays to detect and differentiate Kudoa septempunctata, $K$. thyrsites and $K$. lateolabracis (Myxozoa, Multivalvulida) in muscle tissue of olive flounder (Paralichthys olivaceus). Aquaculture. 338-341. 36-40. https://doi.org/:10.1016/j.aquaculture.2012. 01.022 .

[45] Mathews, P.D., A.A.M. Maia, E.A. Adrianoa. 2016. Morphological and ultrastructural aspects of Myxobolus niger $\mathrm{n}$. sp.(Myxozoa) gill parasite of Corydoras melini (Siluriformes : Callichthyidae) from Brazilian Amazon. Acta Tropica. 158. 214-219

[46] Bobadilla, S.A., H. Schmidt-Posthaus, T. Wahli, J.W. Holland, C.J. Secombes. 2015. Fish immune responses to Myxozoa Chapter 14. Myxozoan Evolution, Ecology and Development. DOI: 10.1007/978-3-31914753-6_14. 